\title{
Eksplorasi Kemampuan Berpikir Kritis Siswa melalui Strategi Experiential Learning pada Materi Fluida Statis
}

\author{
Reni Periyanti ${ }^{1}$, Lia Yuliati ${ }^{1}$, Ahmad Taufiq ${ }^{1}$ \\ ${ }^{1}$ Pendidikan Fisika-Universitas Negeri Malang
}

\section{INFO ARTIKEL}

\section{Riwayat Artikel:}

Diterima: 24-04-2019

Disetujui: 15-07-2019

Kata kunci:
critical thinking skills;
experiential learning strategies;
static fluid;
kemampuan berpikir kritis;
strategi experiential learning;
fluida statis

fluida statis

\author{
Alamat Korespondensi: \\ Reni Periyanti \\ Pendidikan Fisika \\ Universitas Negeri Malang \\ Jalan Semarang 5 Malang \\ E-mail: reniperiyanti94@yahoo.co.id
}

\section{ABSTRAK}

\begin{abstract}
The purpose of this study was to explore students' critical thinking skills on static fluid in the discussion of pressures through experiential learning strategies. This type of research is mixed method with embedded experimental design. The research subjects consisted of 37 students of class XI MIA 2. The measurement instruments in this study were tests of critical thinking skills which numbered 3 items in the form of essays and interview guides. Data analysis techniques include critical thinking ability analysis techniques that are encoded and n-gain analysis techniques. The results of this study indicate that students' critical thinking skills increase after learning using experiential learning strategies. This is indicated by changes in students' thinking for the better. The results of the n-gain analysis are 0.52 which indicates an increase in students' critical thinking skills in the medium category.
\end{abstract}

\begin{abstract}
Abstrak: Penelitian ini bertujuan untuk mengeksplorasi kemampuan berpikir kritis siswa pada materi fluida statis subbab tekanan melalui strategi experiential learning. Jenis penelitian ini yaitu mixed method dengan model embedded experimental design. Subjek penelitian yang terdiri dari 37 orang siswa kelas XI MIA 2. Instrumen pengukuran dalam penelitian ini yaitu tes kemampuan berpikir kritis yang berjumlah tiga butir soal dalam bentuk esai dan panduan wawancara. Teknik analisis data, meliputi teknik analisis kemampuan berpikir kritis yang dicoding dan teknik analisis n-gain. Hasil penelitian ini menunjukkan bahwa kemampuan berpikir kritis siswa mengalami peningkatan setelah dilaksanakan pembelajaran menggunakan strategi experiential learning. Hal ini ditunjukkan dengan perubahan pemikiran siswa menjadi lebih baik sesuai dengan konsep tekanan hidrostatis, Hukum Pascal dan Hukum Archimedes. Adapun hasil analisis n-gain sebesar 0,52 yang menunjukkan peningkatan kemampuan berpikir kritis siswa termasuk pada kategori sedang.
\end{abstract}

Konsep fluida statis sangat berperan penting dalam kehidupan sehari-hari, tetapi kebanyakan siswa belum dapat berpikir secara logis sesuai konsep ilmiah untuk menyelesaikan suatu permasalahan dalam kehidupan sehari-hari (Gotoh, 2016; Nurhasanah, dkk, 2017). Beberapa masalah yang ditemui yaitu sebagian siswa menyatakan tekanan hidrostatis di semua titik pada fluida akan selalu sama besar (Goszewski, dkk, 2013). Sebagian besar siswa menyatakan bahwa kedalaman fluida diukur dari dasar wadah fluida tersebut (Besson, 2004). Selanjutnya siswa sering menafsirkan bahwa tekanan pada bejana tertutup selalu sama di semua bagian cairan (Chen, dkk, 2013; Hanni, dkk, 2018). Selain itu, siswa beranggapan bahwa yang menyebabkan suatu benda dapat terapung, melayang dan tenggelam adalah ukuran dari benda tersebut seperti benda yang besar akan tenggelam sedangkan benda kecil akan melayang (Loverude, dkk, 2003; Ünal \& Costu, 2005; Yin \& Tomita, 2001). Untuk mengatasi hal tersebut maka diperlukan kemampuan yang harus dikembangkan oleh siswa seperti kemampuan berpikir kritis (Brannan, dkk, 2015; Hamilton \& Klebba, 2011). Hal itu karena kemampuan berpikir kritis termasuk salah satu aspek penting dalam sains (Tiruneh, dkk, 2016).

Berpikir kritis adalah proses yang terjadi secara bertahap, siswa memiliki kemampuan untuk merenungkan, memperkaya pengetahuan baru dan mengakuisisi (Piergiovanni, 2014). Kemampuan siswa dalam mengajukan pertanyaan sistematis merupakan bagian penting dari berpikir kritis (Facione, 2011). Adapun menurut Fazriyah, dkk (2018) berpikir kritis merupakan suatu upaya untuk menggunakan keterampilan maupun strategi yang dapat memecahkan suatu permasalahan secara logis. Oleh karena itu, perlunya siswa untuk mengembangkan kemampuan berpikir krtitis dalam diri mereka. Untuk mengembangkan kemampuan berpikir kritis siswa maka guru perlu menciptakan kegiatan berbasis pengalaman yang menciptakan keterlibatan siswa secara aktif dalam pembelajaran (Sulaiman, 2013). Kegiatan berbasis pengalaman melibatkan panca indera sehingga melalui pengamatan siswa dapat lebih mudah mempelajari suatu konsep yang abstrak (Sholihah, dkk, 2016). Belajar dengan 
melakukan sesuatu dan mengintegrasikannya dapat dengan kuat memengaruhi pemikiran siswa (Brewer, 2015). Berdasarkan hal tersebut, untuk mengembangkan kemampuan berpikir kritis siswa diperlukan strategi berbasis pengalaman yaitu strategi experiential learning (Hamilton \& Klebba, 2011; Nurhasanah, dkk, 2017; Wayan, dkk, 2014).

Experiential learning adalah strategi pembelajaran yang menekankan pada pengalaman siswa melalui panca indera dan tindakan sebagai sumber dari belajar (Kolb \& Kolb, 2017). Pembelajaran tersebut mendorong siswa terlibat secara aktif sehingga merasakan kebermaknaan. Selain itu, membuat siswa lebih percaya diri dalam melakukan, mengambil keputusan dan mempresentasikan hasil pengamatannya di depan kelas (Naufalin, dkk, 2017). Karakteristik dari strategi experiential learning, antara lain (1) belajar yang paling baik dipahami pada bagian proses bukan hasil, (2) belajar didasarkan pada pengalaman yang berkelanjutan, (3) proses pembelajaran membutuhkan resolusi konflik-konflik antara gaya-gaya yang di tentang secara dialektis untuk adaptasi dengan dunia, (4) belajar merupakan proses holistik untuk adaptasi dengan dunia, (5) belajar melibatkan interaksi siswa dengan lingkungan, dan (6) belajar merupakan proses menciptakan pengetahuan. Adapun tahapan-tahapan strategi experiential learning yaitu pengalaman konkret, observasi reflektif, konseptualisasi secara abstrak dan eksperimen aktif (Kolb, 1984). Dalam menerapkan strategi experiential learning perlu adanya interaksi sosial yang baik antara siswa dengan guru, siswa dengan siswa maupun siswa dengan lingkungannya (Wahyuningsih, 2014). Pada penelitian sebelumnya, terjadi peningkatan hasil belajar siswa setelah dilakukan pembelajaran menggunakan strategi experiential learning (Sriani, dkk, 2015). Menurut Rodliyah, dkk, (2018) menyatakan bahwa melalui strategi experiential learning siswa dapat membangun suatu konsep.

Adapun hasil penelitian lainnya menunjukkan bahwa kemampuan berpikir kritis siswa mengalami peningkatan setelah pembelajaran melalui strategi experiential learning pada materi fluida statis (Nurhasanah, dkk, 2017). Selanjutnya, menurut Wayan, dkk (2014) terdapat perbedaan kemampuan berpikir kritis dan motivasi siswa yang dibelajarkan melalui strategi experiential learning dari pada siswa yang dibelajarkan melalui model konvensional pada materi fluida statis. Pengunaan strategi experiential learning dalam pembelajaran sangat praktis dan layak untuk meningkatkan kemampuan berpikir kritis siswa. Teknik pengalaman yang diberikan secara langsung dapat memengaruhi pembelajaran. Hal ini dapat mendorong proses kognitif dan pengetahuan siswa yang merupakan dasar untuk mengembangkan kemampuan berpikir kritis (Dvergsten \& Haugen, 2015; Hamilton \& Klebba, 2011). Dapat dikatakan bahwa strategi experiential learning sangat cocok diterapkan untuk mengembangkan kemampuan berpikir kritis siswa.

Berdasarkan hasil penelitian sebelumnya, pembelajaran menggunakan strategi experiential learning dapat meningkatkan kemampuan berpikir kritis siswa pada materi fluida statis. Sehingga untuk mengeksplorasi kemampuan berpikir kritis siswa dalam penelitian ini maka diperlukan kegiatan berbasis pengalaman. Hal tersebut sesuai dengan karakteristik dari strategi experiential learning yaitu pembelajaran yang lebih menekankan pada proses mendapatkan pengalaman secara langsung. Oleh karena itu, tujuan penulisan arikel ini untuk mengeksplorasi kemampuan berpikir kritis siswa melalui strategi experiential learning.

\section{METODE}

Penetian ini adalah penelitian mixed method dengan model embedded experimental design, desain penelitian dengan metode kuantitatif dan kualitatif yang dilakukan secara bersama-sama. Subjek penelitian yaitu siswa kelas XI MIA 2 SMAN 1 Nunukan Kalimantan Utara yang berjumlah 37 orang pada semester ganjil tahun ajaran 2018/2019. Untuk data kuantitatif dan data kualitatif dipilih secara purposive sampling. Adapun instrumen perlakuan berupa silabus, rencana pelaksanaan pembelajaran dan lembar kerja siswa sedangan intrumen pengukuran berupa tes kemampuan berpikir kritis dan panduan wawancara.

Teknik pengumpulan data dilakukan melalui tes dan wawancara. Instrumen tes sebanyak tiga butir soal yang mencakup tekanan hidrostatis, Hukum Pascal dan Hukum Archimedes dalam bentuk essay. Sebelum pembelajaran, peneliti melaksanakan pretest untuk mengetahui kemampuan awal siswa. Selanjutnya melakukan pembelajaran menggunakan strategi experiential learning sebanyak 3 kali pertemuan dengan jumlah sembilan jam pelajaran dan setelah seluruh pembelajaran selesai peneliti melakukan posttest. Adapun tahapan pada strategi experiential larning yaitu concrete experience, reflective observation, abstract conceptualization dan active experimentation. Pada tahap concrete experience siswa menciptakan pengalamannya sendiri dengan cara melakukan percobaan. Kemudian siswa menjawab pertanyaan dari guru pada tahap reflective observation. Selanjutnya pada tahap abstract conceptualization siswa menggunakan pengetahuan yang telah dimilikinya untuk menganalisis hasil percobaan dan siswa menyelesaikan permasalahan dalam kehidupan sehari-hari pada tahap active experimentation.

Analisis data kuantitatif berupa peningkatan kemampuan berpikir kritis siswa yang diperoleh dari hasil analisis n-gain. Sementara itu, analisis data kualitatif berupa hasil wawancara untuk menggali informasi yang berkaitan dengan jawaban siswa pada saat pretest dan posttest. Hasil wawancara selanjutnya dicoding sesuai dengan kategori kemampuan berpikir kritis Ennis \& Weir (2013) yaitu tidak memenuhi standar berpikir kritis (0), memenuhi standar minimal berpikir kritis (1), memenuhi standar berpikir kritis (2) dan memenuhi standar maksimal berpikir kritis (3). 


\section{HASIL}

Kemampuan Berpikir Kritis Siswa pada Materi Fluida Statis

Persentase jawaban siswa pada saat pretest dan posttest beserta kategori berpikir kritis dapat dilihat pada tabel 1 .

Tabel 1. Hasil Perhitungan Persentase Jawaban Siswa saat Pretest dan Posttest

\begin{tabular}{|c|c|c|c|c|c|}
\hline $\begin{array}{l}\text { No. } \\
\text { Soal }\end{array}$ & Indikator Berpikir Kritis & Jawaban & Level & $\begin{array}{l}\text { Persentase } \\
\text { Pretest }\end{array}$ & $\begin{array}{l}\text { Persentase } \\
\text { Posttest }\end{array}$ \\
\hline \multirow[t]{4}{*}{1} & \multirow{4}{*}{$\begin{array}{l}\text { Siswa dapat mengobservasi dan mempertimbangkan hasil observasinya } \\
\text { dalam menentukan bendungan yang tepat sesuai dengan konsep tekanan } \\
\text { hidrostatis. }\end{array}$} & \multirow[t]{2}{*}{ Tepat } & 3 & 21,63 & 72,97 \\
\hline & & & 2 & 29,73 & 16,22 \\
\hline & & \multirow{2}{*}{$\begin{array}{l}\text { Tidak } \\
\text { tepat }\end{array}$} & 1 & 32,43 & 10,81 \\
\hline & & & 0 & 16,22 & - \\
\hline \multirow[t]{4}{*}{2} & \multirow{4}{*}{$\begin{array}{l}\text { Siswa dapat memfokuskan pertanyaan dalam menjelaskan selisih } \\
\text { tekanan di setiap titik pada lift hidrolik. }\end{array}$} & \multirow[t]{2}{*}{ Tepat } & 3 & - & 29,73 \\
\hline & & & 2 & 2.70 & 2,70 \\
\hline & & \multirow{2}{*}{$\begin{array}{l}\text { Tidak } \\
\text { Tepat }\end{array}$} & 1 & 18.92 & 10,81 \\
\hline & & & 0 & 78,38 & 56,76 \\
\hline \multirow[t]{4}{*}{3} & \multirow{4}{*}{$\begin{array}{l}\text { Siswa dapat mendefinisikan istilah dan mempertimbangkan definisi } \\
\text { dengan menerapkan prinsip hukum Archimedes pada fenomena sehari- } \\
\text { hari. }\end{array}$} & \multirow[t]{2}{*}{ Tepat } & 3 & 16,22 & 67,57 \\
\hline & & & 2 & 32,43 & 24,32 \\
\hline & & \multirow{2}{*}{$\begin{array}{l}\text { Tidak } \\
\text { Tepat }\end{array}$} & 1 & 29,73 & 5,41 \\
\hline & & & 0 & 21,62 & 2,70 \\
\hline
\end{tabular}

Berdasarkan tabel 1, persentase jawaban siswa yang tergolong tepat lebih banyak pada saat posttest daripada saat pretest. Gambar 1, 4, dan 7 merupakan butir soal dan gambar 2, 3, 5, 6, 8, dan 9 merupakan contoh jawaban siswa saat pretest dan posttest yaitu sebagai berikut.

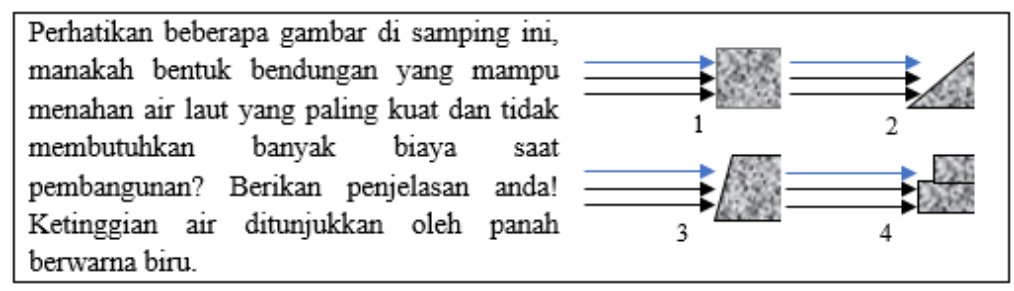

\section{Gambar 1. Butir Soal Tekanan Hidrostatis}

Bentuk bendungan nomor 2, karena sesuai dengan Hukum Pascal bahwa semakin kebawah tekanan yang diterima dinding bendungan semakin besar.

(a)

Bentuk bendungan nomor 3 , karena semakin bertambahnya kedalaman maka tekanan yang diterima oleh dinding bendungan semakin besar.

(b)

\section{Gambar 2. (a) Contoh Jawaban Pretest yang Tidak Tepat (b) Contoh Jawaban Pretest yang Tepat}

Gambar 2 merupakan contoh jawaban siswa saat pretest, adapun (a) siswa beranggapan bahwa nomor 2 merupakan bentuk dinding bendungan yang lebih hemat dan peristiwa tersebut merupakan penerapan dari Hukum Pascal dan (b) siswa beranggapan bahwa bentuk bendungan yang kuat dan lebih hemat biaya adalah nomor 3 karena semakin bertambah kedalaman maka semakin besar tekanan yang diterima oleh dinding bendungan.

Bentuk bendungan nomor 3 , dinding bendungan pada bagian bawahnya dibuat lebih tebal karena bagian bawah menerima tekanan lebih besar dari pada bagian atas, baik tekanan hidrostatis maupun tekanan dari atas bendungan. Selain itu, bentuk bendungan lebih hemat biaya dari pada bentuk lainnya. 
Gambar 3 merupakan contoh jawaban siswa saat posttest, siswa telah menyadari bahwa pada bagian bawah dinding bendungan mendapatkan tekanan hidrostatis lebih besar daripada bagian atasnya sesuai dengan konsep tekanan hidrostatis.

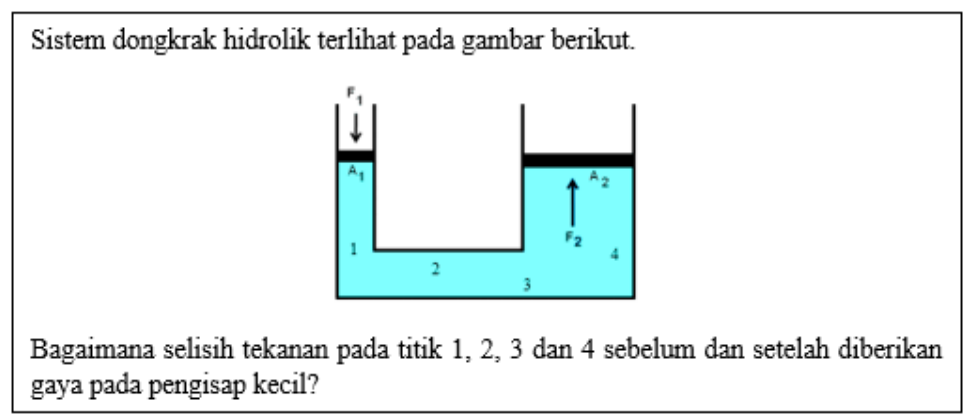

\section{Gambar 4. Butir Soal Hukum Pascal}

Selisih tekanan pada titik $1<$ titik $2<$ titik $3<$ titik 4

\section{Gambar 5. Contoh Jawaban Pretest yang Tidak Tepat}

Gambar 5 merupakan contoh jawaban siswa yang tidak tepat saat pretest. Siswa menganggap bahwa selisih tekanan pada bejana tertutup bergantung pada arah gerak cairan.

Sebelum diberikan gaya pada pengisap kecil titik 1,2,3 dan 4 memiliki tekanan yang berbeda, karena berada pada posisi yang berbeda. Tetapi, setelah diberikan gaya pada pengisap kecil titik 1,2,3 dan 4 memiliki tekanan yang sama.

(a)

Selisih tekanan pada titik 1,2,3 dan 4 sebelum dan setelah diberikan gaya pada pengisap kecil adalah sama. Karena $P_{1}=P_{2}$ sehingga berapapun besar gaya pada pengisap kecil maka akan menghasilkan tekanan zat cair dalam ruang tertutup yang diteruskan kesegala arah dengan sama besar sesuai dengan bunyi Hukum Pascal.

(b)

\section{Gambar 6. (a) Contoh Jawaban Posttest yang Tidak Tepat (b) Contoh Jawaban Posttest yang Tepat}

Gambar 6 merupakan contoh jawaban siswa saat posttest. (a) Siswa beranggapan bahwa sebelum diberikan gaya pada pengisap kecil tekanan keempat titik berbeda dan setelah diberikan gaya tekanan keempat titik sama besar adapun (b) siswa yang menganggap bahwa selisih tekanan pada keempat titik sama besar. 
Perhatikan gambar di bawah ini.

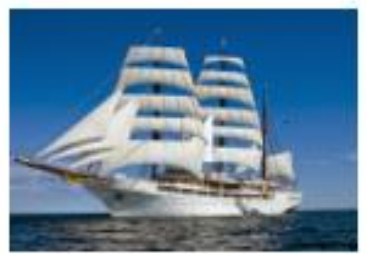

Gambar di atas adalah gambar kapal yang mengapung di permukaan laut. Berdasarkan hal tersebut, apa yang menyebabkan kapal tersebut tidak tenggelam padahal ukurannya cukup besar?

\section{Gambar 7. Butir Soal Hukum Archimdes}

Bentuk kapal yang seperti mangkuk atau cekungan sehingga membuat kapal mengapung di permukaan air laut.

(a)

Gaya apung yang menyebabkan kapal dapat terapung

(b)

Gambar 8. (a) Contoh Jawaban Pretest yang Tidak Tepat (b) Contoh Jawaban Pretest yang Tepat

Gambar 8 merupakan contoh jawaban siswa saat pretest. (a) Siswa beranggapan bahwa bentuk kapal yang seperti mangkuk membuat kapal terapung dan (b) anggapan siswa sudah tepat bahwa gaya apung yang menyebabkan kapal terapung.

Karena badan kapal yang mempunyai ruang untuk udara sehingga kapal dapat mengapung.

(a)

Pada badan kapal terdapat rongga udara yang membuat massa jenis keseluruhan kapal lebih kecil dari pada massa jenis air laut. Selain itu, badan kapal yang dibuat berongga bertujuan agar volume air laut yang dipindahkan oleh badan kapal menjadi lebih besar sehingga gaya angkat yang dihasilkan oleh air laut juga besar. Gaya angkat inilah yang mampu melawan berat kapal, oleh karena itu kapal tetap mengapung dipermukaan laut.

(b)

\section{Gambar 9. (a) Contoh Jawaban Posttest yang Tidak Tepat (b) Contoh Jawaban Posttest yang Tepat}

Gambar 9 merupakan contoh jawaban siswa saat posttest. (a) Siswa beranggapan udara di dalam kapal yang menyebabkan kapal mengapung dan (b) anggapan siswa sudah tepat karena menjawab massa jenis keseluruhan kapal yang lebih kecil dari air laut dan gaya apung yang menyebabkan kapal mengapung di permukaan air. Adapun peningkatan kemampuan berpikir kritis siswa setelah pembelajaran menggunakan strategi experiential learning yang ditunjukkan oleh hasil analisis n-gain dapat dilihat pada tabel 2 .

Tabel 2. Hasil Analisis N-Gain

\begin{tabular}{ccccc}
\hline Tes & Jumlah Skor Siswa & Rata-Rata & N-Gain & Kategori \\
\cline { 1 - 3 } Pretest & 1333 & 36,04 & \multirow{2}{*}{0,52} & Sedang \\
\cline { 1 - 3 } Posttest & 2567 & 69,37 & & \\
\hline
\end{tabular}

Berdasarkan tabel 2, peningkatan kemampuan berpikir kritis siswa saat pretest-posttest sebesar 0,52 termasuk dalam kategori sedang. 


\section{Hasil Wawancara}

Hasil wawancara siswa dengan guru yang berguna sebagai informasi tambahan mengenai jawaban siswa saat pretest dan posttest dapat dilihat pada tabel 3.

Tabel 3. Hasil Wawancara

\begin{tabular}{|c|c|c|}
\hline Sub Materi & Pretest & Posttest \\
\hline $\begin{array}{l}\text { Tekanan } \\
\text { Hidrostatis }\end{array}$ & $\begin{array}{l}\text { Siswa memilih bentuk bendungan nomor } 3 \text { pada } \\
\text { bagian bawah dibuat lebih tebal karena bagian bawah } \\
\text { mendapatkan tekanan hidrostatis lebih besar baik } \\
\text { tekanan air dalam bendungan maupun tekanan di atas } \\
\text { bendungan. Selain itu, bentuk bendungan tersebut } \\
\text { lebih kuat sehingga dapat memperlambat terjadinya } \\
\text { pengikisan. Kemampuan berpikir kritis siswa } \\
\text { tergolong maksimal. } \\
\text { Siswa memilih bentuk bendungan nomor } 3 \text { karena } \\
\text { semakin bertambah ketinggian fluida maka tekanan } \\
\text { hidrostatis semakin besar. Hal tersebut karena siswa } \\
\text { tidak menyadari bahwa faktor penyebab terjadinya } \\
\text { tekanan hidrostatis salah satunya adalah kedalaman } \\
\text { fluida bukan ketinggian. Kemampuan berpikir kritis } \\
\text { siswa tergolong minimal. } \\
\text { Siswa memilih bentuk bendungan nomor } 2 \text { karena } \\
\text { hanya berpikir bahwa dasar bendungan mendapatkan } \\
\text { tekanan lebih besar dari pada bagian atasnya tanpa } \\
\text { memperhatikan biaya pembangunan dinding } \\
\text { bendungan dan teriadinya erosi. }\end{array}$ & $\begin{array}{l}\text { Siswa memilih nomor } 3 \text { karena tekanan hidrostatis salah } \\
\text { satunya dipengaruhi oleh kedalaman air, semakin } \\
\text { bertambahnya kedalaman air maka tekanan hidrostatisnya } \\
\text { semakin besar sehingga pada bagian bawah bendungan } \\
\text { harus dibuat lebih tebal daripada bagian atasnya agar dapat } \\
\text { menahan tekanan yang disebabkan oleh air dan tekanan } \\
\text { udara diatas bendungan. Bentuk seperti gambar nomor } 3 \\
\text { lebih hemat biaya dan lebih kokoh dan tidak mudah jebol } \\
\text { akibat erosi yang ditimbulkan oleh air. Kemampuan } \\
\text { berpikir kritis siswa tergolong maksimal. } \\
\text { Siswa memilih nomor } 3 \text { dan beranggapan bahwa bentuk } \\
\text { tersebut dapat menahan tekanan yang disebabkan oleh air. } \\
\text { Pilihan siswa sudah tepat, hanya saja kemampuan berpikir } \\
\text { kritisnya masih tergolong standar. Siswa tergolong } \\
\text { memenuhi standar berpikir kritis. } \\
\text { Siswa memilih nomor } 3 \text { tetapi tidak dapat memberikan } \\
\text { penjelasan. Hal tersebut karena siswa belum sepenuhnya } \\
\text { memahami konsep tekanan hidrostatis. Kemampuan } \\
\text { berpikir kritis siswa tergolong minimal. }\end{array}$ \\
\hline
\end{tabular}

Selain itu, siswa tidak menyadari bahwa kasus tersebut adalah tekanan hidrostatis. Siswa tersebut tergolong tidak memenuhi standar berpikir kritis.

$\begin{array}{ll}\text { Hukum } & \text { Siswa menjawab bahwa selisih tekanannya sama. } \\ \text { Pascal } & \text { Jawaban siswa tersebut masih menunjukkan bahwa } \\ & \text { kemampuan berpikir kritisnya standar karena tidak } \\ \text { memberikan penjelasan lanjutan terkait jawaban yang } & \\ \text { diberikan. } & \text { Siswa menjawab bahwa titik yang berada dekat dengan } \\ & \text { dasar bejana mendapatkan tekanan yang lebih besar } \\ & \text { karena tekanan di pengaruhi oleh kedalaman. Siswa } \\ & \text { beranggapan bahwa kasus tersebut merupakan tekanan } \\ \text { hidrostatis. Kemampuan berpikir kritis siswa tergolong } & \text { minimal. }\end{array}$

Siswa menjawab bahwa selisih tekanan pada titik 1 lebih besar dari pada titik 2,titik 2 lebih besar dari titik 3 dan titik 3 lebih besar dari titik 4 karena cairan berjalan dari kiri ke kanan. Hal tersebut karena siswa belum menyadari bahwa kasus tersebut adalah Hukum Pascal. Siswa tersebut tergolong tidak memenuhi standar berpikir kritis.

$\begin{array}{cl}\text { Hukum } & \text { standar berpikir kritis. } \\ \text { Archimedes } & \text { Siswa menjawab karena gaya angkat air laut dan massa } \\ & \text { jenis kapal yang lebih kecil dari pada air laut. Siswa } \\ & \text { sudah termasuk dalam kategori maksimal. } \\ & \text { Siswa menjawab karena massa jenis air laut lebih besar } \\ & \text { dari pada massa jenis keseluruhan kapal sehingga kapal } \\ & \text { dapat mengapung. Penjelasan siswa belum lengkap } \\ & \text { karena tidak memperhatikan faktor lainnya. Siswa } \\ & \text { tergolong memenuhi standar berpikir kritis. } \\ & \text { Siswa menjawab karena badan kapal yang berukuran } \\ & \text { besar. Siswa beranggapan bahwa ukuran benda } \\ & \text { menjadi faktor penyebab benda dapat terapung. Siswa } \\ & \text { tergolong tidak memiliki kemampuan berpikir kritis. }\end{array}$

Siswa menjawab bahwa tekanan pada keempat titik sebelum dan setelah diberikan gaya pada pengisap kecil adalah berbeda, tetapi memiliki selisih tekanan yang sama sesuai dengan Hukum Pascal bahwa jika diberikan gaya pada salah satu pengisap pada bejana tertutup maka akan menghasilkan tekanan ke segala arah dengan sama besar. Kemampuan berpikir kritis siswa tergolong maksimal.

Siswa menjawab bahwa tekanan pada titik 3 lebih besar dari pada titik 2, titik 2 lebih besar dari titik 4 dan titik 4 lebih besar dari titik 1 . Hal tersebut karena siswa beranggapan peristiwa tersebut adalah tekanan hidrostatis. Kemampuan berpikir kritis siswa tergolong minimal.

Siswa menjawab tekanan pada keempat titik sebelum dan setelah diberikan gaya tetap sama tidak ada perubahan sehingga tidak memiliki selisih. Siswa masih belum menyadari bahwa peristiwa tersebut adalah Hukum Pascal. Siswa tersebut tergolong tidak memenuhi standar berpikir kritis.

Siswa menjawab bahwa badan kapal dibuat berongga yang berisi udara, sehingga membuat massa jenis kapal secara keseluruhan lebih ringan dari pada massa jenis air laut. Adapun kapal dibuat berongga agar volume air yang dipindahkan besar sehingga menghasilkan gaya angkat yang besar. Gaya angkat yang mampu menahan kapal agar tidak tenggelam. Kemampuan berpikir kritis siswa sudah maksimal.

Siswa menjawab bahwa rongga udara yang berada di badan kapal membuat kapal tersebut mengapung. Kemampuan berpikir kritis siswa tersebut masih tergolong minim karena masih belum memahami Hukum Archimedes secara keseluruhan.

Satu orang siswa masih belum memiliki kemampuan berpikir kritis pada Hukum Archimedes. 


\section{PEMBAHASAN}

Pada soal tekanan hidrostatis saat pretest sebagian besar kemampuan berpikir kritis siswa masih tergolong memenuhi standar minimal dan tidak memenuhi standar. Hal tersebut dikarenakan siswa beranggapan bahwa faktor yang menyebabkan tekanan hidrostatis adalah ketinggian fluida bukan kedalaman fluida. Dengan begitu siswa belum tepat menafsirkan variabel $h$ pada tekanan hidrostatis yang merupakan kedalaman bukan ketinggian fluida sama dengan penelitian Besson (2004). Adapun siswa yang belum tepat karena memilih bendungan nomor 2 dan menganggap bahwa kasus tersebut adalah kasus Hukum Pascal, hal itu karena kurangnya pengetahuan awal siswa pada materi fluida statis.

Saat posttest, siswa mengalami perubahan pemikiran yang ditunjukkan oleh banyaknya jumlah siswa yang tergolong pada kategori memenuhi standar dan memenuhi standar maksimal. Hal tersebut karena sebagian besar siswa memilih bentuk bendungan nomor 3 karena semakin bertambah kedalaman fluida maka akan semakin besar tekanan hidrostatis yang diterima oleh dinding bendungan sehingga pada bagian bawah dibuat tebal dari pada bagian atasnya. Tetapi bagian atas tidak begitu tipis agar tidak mudah jebol akibat erosi yang diakibatkan oleh air sesuai dengan Serway \& Jewett (2006).

Perubahan pemikiran setelah dilakukan pembelajaran menggunakan strategi experiential learning menngakibatkan terjadinya peningkatan kemampuan berpikir kritis siswa. Pada tahap concrete experience siswa memahami konsep yang abstrak dengan cara melakukan percobaan tekanan hidrostatis. Saat percobaan siswa mengamati perubahan ketinggian pada pipa U ketika corong dimasukkan ke dalam air maupun larutan garam. Kemudian pada tahap reflective observation siswa menjawab pertanyaan dari guru mengenai faktor-faktor yang menyebabkan perubahan ketinggian saat corong dimasukkan ke dalam air atau larutan garam dan siswa menggunakan pengetahuannnya untuk menganalisis hasil percobaan yang telah ditemukan pada tahap abstract conceptualization. Selanjutnya pada tahap active experimentation siswa menggunakan konsep yang dimilikinya untuk menyelesaikan masalah yang terkait pemasangan infus yang harus memperhatikan tekanan darah pasien dan posisi infus tersebut. Hal tersebut sejalan dengan penelitian Sholihah, dkk (2016).

Pada soal Hukum Pascal saat pretest tidak terdapat siswa yang tergolong dalam kategori memenuhi standar maksimum, hampir seluruh siswa termasuk dalam kategori tidak memenuhi standar berpikir kritis. Siswa beranggapan bahwa kasus tersebut merupakan tekanan hidrostatis sehingga siswa menjawab semakin mendekati dasar bejana maka akan mendapatkan tekanan yang semakin besar. Hal tersebut sesuai dengan penelitian Hanni, dkk (2018) dan Chen, dkk (2013) bahwa sebagian besar siswa masih memiliki gagasan yang kurang mengenai Hukum Pacal seperti halnya siswa menganggap bahwa selisih tekanan yang sama hanya berlaku pada ketinggian yang sama. Saat posttest, pemikiran siswa mengalami perubahan walaupun tidak sebagian dari jumlah keseluruhan, terdapat beberapa siswa yang termasuk pada kategori memenuhi standar maksimal dan memenuhi standar. Hal tersebut karena banyaknya siswa yang masih belum fokus pada pertanyaan yang diberikan oleh guru mengenai Hukum Pascal. Adapun beberapa siswa beranggapan sudah tepat bahwa ketika diberikan gaya pada pengisap kecil maka tekanan akan diteruskan sama besar ke segala arah sehingga pada titik 1, 2, 3 dan 4 memiliki selisih tekanan yang sama besar sesuai dengan Knight (2017).

Anggapan beberapa siswa sudah tepat setelah pembelajaan menggunakan strategi experiential learning yang menunjukkan terjadinya peningkatan kemampuan berpikir kritis siswa. Pada tahap concrete experience siswa melakukan percobaan Hukum Pascal untuk memahami konsep yang abstrak. Selanjutnya siswa menjawab pertanyaan dari guru mengenai faktor-faktor memengaruhi tekanan yang diteruskan sama besar ke segala arah pada tahap reflective observation. Kemudian pada tahap abstract conceptualization siswa menggunakan pengetahuannya untuk menganalisis hasil percobaan Hukum Pascal dan menggunakan konsep yang dimiliki untuk mengatasi permasalahan dalam kehidupan sehari-hari seperti mengidentifikasi dongkrak hidrolik yang berukuran kecil dapat mengangkat sebuah mobil yang massanya ribuan kilogram pada tahap active experimentation. Hal tersebut sejalan dengan penelitian Dvergsten \& Haugen (2015).

Pada soal Hukum Archimedes saat pretest sebagian besar siswa beraggapan bahwa ukuran badan kapal yang besar membuat kapal dapat mengapung. Anggapan siswa tersebut masuk pada kategori tidak memenuhi standar berpikir kritis. Sejalan dengan penelitian Yin \& Tomit (2001) bahwa benda yang kosong selalu terapung karena adanya udara di dalam benda tersebut. Kebanyakan siswa memiliki gagasan yang salah mengenai benda yang terapung, salah satunya karena mereka tidak mengakui peran penting dari volume yang dipindahkan untuk menentukan gaya apung sejalan dengan penelitian Loverude (2009).

Adapun saat posttet, siswa telah mengalami perubahan pemikiran yang ditandai dengan sebagian besar sisa tergolong pada kategori memenuhi standar dan memenuhi standar maksimal. Siswa beranggapan bahwa badan kapal yang memiliki rongga berisi udara membuat massa jenis keseluruhan kapal menjadi lebih ringan daripada massa jenis air laut. Selain itu, bentuk badan kapal yang berongga membuat volume air yang dipindahkan oleh badan kapal tersebut menjadi lebih besar sehingga mendapatkan gaya angkat yang besar pula. Gaya angkat ini yang dapat menahan beratnya kapal yang berukuran besar. Hal tersebut sesuai dengan Serway \& Jewett (2006) bahwa besarnya gaya apung berbanding lurus dengan volume zat cair yang dipindahkan.

Sebagian besar siswa mengalami perubahan pemikiran menjadi lebih baik setelah dilakukan pembelajaran menggunakan strategi experiential learning yang menunjukkan bahwa terjadinya peningkatan kemampuan berpikir kritis siswa. Pada tahap concrete experience siswa melakukan percobaan Hukum Archimedes untuk memahami konsep yang abstrak, saat percobaan siswa menyelidiki hubungan gaya angkat dengan berat air yang dipindahkan dan hubungan volume benda yang tercelup dengan volume air yang dipindahkan. Kemudian pada tahap reflective observation siswa menjawab pertanyaan dari guru terkait faktorfaktor yang memengaruhi prinsip Hukum Archimedes dan siswa menggunakan pengetahuan yang dimilikinya untuk menganalisis hasil percobaan. Selanjutnya siswa menggunakan konsep yang dimilikinya untuk mengidentifikasi penyebab kapal yang 
berukuran besar dapat mengapung dan penyebab kapal selam dapat mengapung, tenggelam dan melayang pada tahap active experimentation. Hal tersebut sejalan dengan penelitian Nurhasanah, dkk (2017).

Berdasarkan hasil penelitian menunjukkan bahwa kemampuan berpikir kritis siswa menjadi lebih baik setelah dilaksanakan pembelajaran melalui strategi experiential learning. Terjadi peningkatan kemampuan berpikir kritis siswa saat pretest-posttest yang ditunjukkan oleh hasil analisis n-gain sebesar 0,52 termasuk pada kategori sedang dan perubahan pemikiran siswa. Hal tersebut karena kegiatan mengamati melalui panca indera mampu membuat siswa lebih mudah mempelajari sesuatu untuk menciptakan ide yang baru (Piergiovanni, 2014). Dengan mengamati dan merenungkan siswa dapat berpikir secara logis sesuai dengan konsep ilmiah (Gotoh, 2016). Adapun menurut Yashusi melalui kegiatan mengamati siswa dapat merefleksikan masalah yang dihadapi secara mandiri. Selanjutnya menurut Dvergsten \& Haugen (2015) bahwa kegiatan yang konkrit dalam pembelajaran mampu menumbuhkan rasa percaya diri siswa sehingga kemampuan berpikir siswa dapat berkembang. Selain itu, menurut Hamilton \& Klebba (2011) bahwa kegiatan memperoleh pengalaman melalui strategi experiential learning merupakan cara yang sangat mudah untuk meningkatkan kemampuan berpikir siswa.

\section{SIMPULAN}

Berdasarkan hasil penelitian dan pembahasan maka dapat disimpulkan bahwa kemampuan berpikir kritis siswa mengalami peningkatan setelah dilaksanakan pembelajaran menggunakan strategi experiential learning. Hal tersebut karena berkurangnya jumlah siswa yang tergolong memenuhi standar minimum dan tidak memenuhi standar berpikir kritis. Pada soal tekanan hidrostatis, sebagian besar siswa sudah tergolong memenuhi standar berpikir kritis karena beranggapan bahwa massa jenis, gaya gravitasi dan kedalaman fluida merupakan faktor yang memengaruhi tekanan hidrostatis, sehingga memilih bentuk bendungan nomor 3. Pada soal Hukum Pascal, sebagian siswa tergolong memenuhi standar berpikir kritis karena menganggap jika diberikan gaya pada pengisap kecil maka akan menghasilkan tekanan yang diteruskan sama besar ke segala arah sehingga selisih tekanan pada empat titik sama besar. Sebagian siswa lainnya masih tergolong tidak memenuhi standar berpikir kritis karena belum menyadari bahwa kasus tersebut adalah Hukum Pascal. Selanjutnya soal Hukum Archimedes, sebagian besar siswa telah tergolong memenuhi standar berpikir kritis karena beranggapan bahwa bentuk badan kapal yang berongga membuat massa jenis keseluruhan kapal yang lebih kecil dari massa jenis air laut dan badan kapal yang dibuat berongga agar volume air yang dipindahkan oleh kapal besar sehingga gaya apungnya juga besar. Hal itulah yang menyebabkan kapal mengapung di laut.

\section{DAFTAR RUJUKAN}

Besson, U. (2004). Students' conceptions of fluids. International Journal of Science Education, 26(14), 1683-1714. https://doi.org/10.1080/0950069042000243745

Brannan, K., Welch, R., Woo, M., Bower, K., Mills, A., \& Watson, M. (2015). Refinement of a Concept Inventory to Assess Conceptual Understanding in Civil Engineering Fluid Mechanics. ASEE Annual Conference \& Exposition https://doi.org/10.18260/p.24659

Chen, Y., Irving, P. W., \& Sayre, E. C. (2013). Epistemic Game for Answer Making in Learning about Hydrostatics. Physical Review Special Topics - Physics Education Research, 9(1), 1-7. https://doi.org/10.1103/PhysRevSTPER.9.010108

Dvergsten, V., \& Haugen, A. (2015). Experiential Learning and its Impact on Critical Thinking. Occupational Therapy Scholarly Projects.

Elen, J., Weldeslassie, A. G., Tiruneh, D. T., De Cock, M., \& Janssen, R. (2016). Measuring Critical Thinking in Physics: Development and Validation of a Critical Thinking Test in Electricity and Magnetism. International Journal of Science and Mathematics Education, 15(4), 663-682. https://doi.org/10.1007/s10763-016-9723-0

Fazriyah, N., Supriyati, Y., \& Rahayu, W. (2018). Watson-Glaser's Critical Thinking Skills Watson- Glaser' s Critical Thinking Skills. 2nd International Conference on Statistics, Mathematics, Teaching, and Research, 1-6.

Fliegel, R., \& Holland, J. (2013). Quantifying Learning in Critical Thinking. The Journal of General Education, 62(2-3), 160203. https://doi.org/10.1353/jge.2013.0015.

Goszewski, M., Moyer, A., Bazan, Z., \& Wagner, D. J. (2013). Exploring student difficulties with pressure in a fluid. AIP Conference Proceedings, 1513(may 2012), 154-157. https://doi.org/10.1063/1.4789675

Gotoh, Y. (2016). Development of Critical Thinking with Metacognitive Regulation. 13th International Conference on Cognition and Exploratory Learning in Digital Age, 353-356.

Hamilton, J. G., \& Klebba, J. M. (2011). Experiential Learning : A Course Design. American Journal of Business Education, 4(12), 1-12.

Hanni, I. U., Muslim, Hasanah, L., \& Samsudin, A. (2018). K-11 Students' Creative Thinking Ability on Static Fluid: A Case Study. Journal of Physics: Conference Series, 1013(1). https://doi.org/10.1088/1742-6596/1013/1/012034

Kolb, A. Y., \& Kolb, D. A. (2017). Experiential Learning Theory as a Guide for Experiential Educators in Higher Education. ELTHE: A Journal for Engaged Educators, 1(1), 7-45.

Kolb, D. A. (1984). Experiential Learning: Experience as The Source of Learning and Development. Prentice Hall, Inc., (1984), 20-38. https://doi.org/10.1016/B978-0-7506-7223-8.50017-4 
Loverude, M. E. (2009). A Research-Based Interactive Lecture Demonstration on Sinking and Floating. American Journal of Physics, 77(10), 897-901. https://doi.org/10.1119/1.3191688

Loverude, M. E., Kautz, C. H., \& Heron, P. R. L. (2003). Helping Students Develop an Understanding of Archimedes' Principle. I. Research on student understanding. American Journal of Physics, 71(11), 1178-1187. https://doi.org/10.1119/1.1607335

Sholihah, M., Utaya, S., \& Susilo, S. (2016). Pengaruh Model Experiential Learning terhadap Kemampuan Berpikir Siswa SMA. Jurnal Pendidikan: Teori, Penelitian, dan Pengembangan, 1(11), 2096-2100.

Naufalin, L. R., Dinanti, A., \& Krisnaresanti, A. (2017). Experiential Learning Model on Entrepreneurship Subject for improving Students' Soft Skills. Dinamika Pendidikan,11(1), 87-98.

Nurhasanah, S., Malik, A., \& Mulhayatiah, D. (2017). Penerapan Model Experiential Learning untuk Meningkatkan. Wahana Pendidikan Fisika, 2(2), 58-62.

Piergiovanni, P. R. (2014). Creating a Critical Thinker. College Teaching, 62(3), 86-93. https://doi.org/10.1080/87567555.2014.896775

Rodliyah, I., Saraswati, S., \& Sa'adah, N. (2018). Implementasi Model Experiential Learning Pada Materi Kelipatan Persekutuan Terkecil dan Faktor Persekutuan Terbesar Kelas IV. Jurnal Gantang, 3(2), 143-151. https://doi.org/10.31629/jg.v3i2.601

Sriani, N. K., Sutama, M., Ayu, I., \& Darmayanti, M. (2015). Penerapan Model Pembelajaran Experiential Learning untuk Meningkatkan Kemampuan Menulis Paragraf Deskripsi pada Siswa Kelas VII B SMP Negeri 2 Tampaksiring. Jurnal Universitas Pendidikan Ganesha Jurusan Pendidikan Bahasa dan Sastra Indonesia, 3(1), 1-11.

Sulaiman, F. (2013). The Effectiveness of PBL Online on Physics Students' Creativity and Critical Thinking: A Case Study at Universiti Malaysia Sabah. International Journal of Education and Research, 1(3), 1-18.

Ünal, S., \& Costu, B. (2005). Problematic Issue for Students: Does it Sink or Float? Asia-Pacific Forum on Science Learning and Teaching, 6(1), 1-16.

Yin, Y., \& Tomita, M. K. (2001). Diagnosing and Dealing with Student Misconceptions: Floating and Sinking. Science Scope, $31(8), 34-39$. 